\title{
The Greek "Rescue": Where Did the Money Go? An Analysis
}

\author{
Pablo G. Bortz ${ }^{1 *}$
}

Working Paper No. 29

November 2015

\begin{abstract}
This paper analyses the financial assistance provided to Greece in the first two rescue packages granted by the Troika (European Union, European Central Bank and IMF). It looks particularly carefully at claims by Sinn that a third of the public credit granted to Greece financed its current account deficit, while another third funded capital flight by Greek nationals, with only the remaining third used to pay creditors. The paper shows that Sinn inflates the assistance given to Greece by mixing several different concepts in the total. It also critically reviews the claim that the assistance was used to finance the current account deficit or capital flight by Greek citizens. Realistic accounting shows that $54 \%$ of the financial assistance provided to Greece was used to repay (foreign) debt, while another $21 \%$ was used to recapitalize Greek banks (some of which were owned by foreign institutions). Other claims about the rescue package are also analysed in relation to the treatment of Greek and foreign banking exposure to sovereign debt.
\end{abstract}

\footnotetext{
${ }^{1}$ University of San Martín, Argentina. Email: pablobortz@yahoo.com. The author is grateful for comments and suggestions from Alfredo Calcagno, Miguel Carrión-Alvarez, Frances Coppola, Dan Davies, Thomas Ferguson, Ramanan Iyer, Jan Kregel, Joerg Mayer, Nicolas Maystre, Pia Malaney, Perry Mehrling, Daniel Munevar, Marianela Sarabia, Servaas Storm, Silke Tober and Edgardo Torija-Zane. All usual caveats apply.
} 


\section{INTRODUCTION}

The government that took power in Greece by the end of January 2015, led by the leftist party Syriza, made debt relief a priority of its campaign. To this end it sought to achieve a reduction in its outstanding public foreign debt by agreement with its creditors. As negotiations reached a tipping point, the International Monetary Fund (IMF) published a Debt Sustainability Analysis (DSA), which showed that, even under assumptions that would be historically unprecedented for Greece, Greek public debt was not sustainable. Resolving Greece's sovereign debt problem required a reduction in its nominal value and/or an extension of maturities for many decades coupled with a reduction in interest rates and a grace period of at least ten years.

Though the IMF principally faults the new government, the reality is that Greek economic performance since the first "rescue" package has been disastrous. Blanchard and Leigh (2013) describe mistakes in the assumptions underlying the projections at the time of the agreements; the IMF has even issued an institutional acknowledgment of the miscalculations (IMF 2013). The government has cut public primary expenditure by $30 \%$ between 2009 and 2014, with huge disinvestment in many areas of the economy. ${ }^{2}$ The fiscal balance has shown one of the largest, if not the largest, reversals in Western countries in peacetime in a century, transforming a primary deficit of $10.3 \%$ of GDP into a primary surplus of $0.4 \%$, despite a cumulative GDP fall of $25 \%{ }^{3}$ However, given this acute drop in GDP, it is not surprising that the public debt to GDP ratio has mounted during this period, despite a restructuring of privately held debts that reduced its nominal value by $€ 107$ billion (Zettelmeyer et al 2013).

In view of the poor performance of the Greek economy, and given the likelihood that those loans will need to be written down, many commentators started to debate where the rescue money had gone. A study published by Macropolis (Mouzakis 2015) ${ }^{4}$ estimated that almost $90 \%$ of the official loans given to Greece ended up in the hands of the original creditors, except a portion that went toward the recapitalization of Greek banks, many of which were owned by foreign institutions. An alternative claim is presented by Hans-Werner Sinn (2015), who takes a much more generous view of the

\footnotetext{
${ }^{2}$ Source: ECB Statistical Data Warehouse, Greece Government Primary Expenditure.

${ }^{3}$ Source: ECB Statistical Data Warehouse.

${ }^{4} \mathrm{http} / / /$ www.macropolis.gr/?i=portal.en.the-agora.2080
} 
financing provided by European countries, the European Central Bank (ECB) and the IMF. A similar perspective is advanced by Bulow and Rogoff (2015), who assert that Greece was a net receiver of generous funds from the Troika (European Commission, ECB and IMF).

Sinn's conclusions, however, are based on an interpretation of the monetary creation mechanisms in the Eurozone that does not reflect the actual operation of the payment system. This erroneous interpretation affects Sinn's demarcation of the time period during which the Eurozone provided "assistance", the amount of such financing, and its eventual beneficiaries. Further, there are factual mistakes regarding the holdings bought by the Securities Market Programme (SMP). Bulow and Rogoff, in turn, take as a net benefit for Greece the fact that the status of its creditors changed from private to official.

In this paper we focus on Sinn's work, which presents a detailed study of the loan granted to Greece. We do not examine here his proposals for the future handling of the Greek economy, his study of the factors leading to the failure of the programme, or the causes of the crisis. This article deals primarily with the packages already implemented, not discussions regarding a third bail out, or alternative policies such as a so-called Grexit.

The structure of the paper is as follows. In the next section, we examine the numbers which Sinn uses to support his claim that the assistance to Greece was generous, in the sense that it financed its current account deficit plus acquisition of foreign assets by Greek nationals, i.e. capital flight. In this section, as in the paper in general, Sinn's arguments and figures will be extensively quoted in order to avoid mischaracterization or misrepresentation of his supporting evidence. Section III criticizes Sinn's dating of the start of public assistance to Greece, which he sets in 2008. In Section IV, we provide a description of the process governing the creation of balances in the payment settlement system of the Eurozone, called TARGET2, which features prominently in Sinn's argumentation and conclusions. This description is necessary to clarify unwarranted implications Sinn draws from it, which the section explores further. Section V examines the issue of the Security Markets Programme (SMP) purchases and the bank recapitalization fund. The next section examines Sinn's capital flight argument. In Section VII we discuss Mouzakis' analysis of the financial assistance to 
Greece and compare it with our own numbers. The final section presents some conclusions.

\section{SINN'S CALCULATIONS}

\subsection{What amount of "Aid"?}

Sinn's report appeared in June 2015. It counts the amount of public credit given to Greece up to March 2015, that is, before the last round of credit to Greece provided at the end of July by the European Financial Stability Mechanism (EFSM). This credit covered Greek liabilities vis-à-vis official bodies such as the ECB and the IMF, liabilities that are included in the calculations of the credit provided by the official sector. Like Sinn, we refrain from including these new credits in our assessment. Sinn distinguishes carefully between sums authorized, pledged, or provided, and sums actually disbursed. He discounts repayments already made to the IMF and the ECB (with the exceptions noted above), plus some other contributions related to Greece's share in the ECB's capital. "Purchases" of European bonds by the Bank of Greece $(\mathrm{BoG})$, the contribution of Greece to the capital of the European Stability Mechanism (ESM), and Greek contribution to the loans provided by the European Financial Stability Facility (EFSF) are also discounted.

Each component of this "public rescue" as of 31 March 2015 is listed, in billions of euros, in table 1 (which essentially repeats table 1 in Sinn (2015: 7)) and is described below. Following Sinn's lead, we will refer only to sums effectively disbursed, which differ from the sums originally authorized and even pledged, particularly in the second package. 
Table 1

(All values are in billions of Euros)

\begin{tabular}{|c|c|c|}
\hline & Concept & Sum disbursed \\
\hline \multirow{11}{*}{ 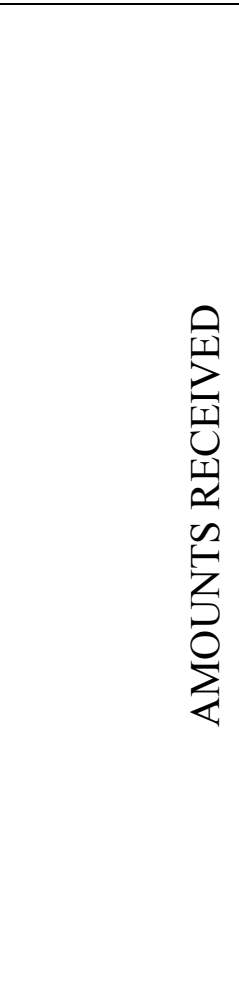 } & i) First package & 73.2 \\
\hline & Euro countries' portion & 52.9 \\
\hline & IMF portion & 20.3 \\
\hline & ii) Second package & 142.6 \\
\hline & EFSF portion & 130.9 \\
\hline & IMF portion & 11.7 \\
\hline & Total i + ii & 215.8 \\
\hline & iii) SMP purchases & 17.2 \\
\hline & $\begin{array}{l}\text { iv) TARGET2 liabilities of } \\
\text { the BoG }\end{array}$ & 96.4 \\
\hline & $\begin{array}{l}\text { v) Over-proportionate } \\
\text { banknote issuance by the BoG }\end{array}$ & 14.0 \\
\hline & $\begin{array}{l}\text { Total received (i) }+(\text { ii })+(\text { iii }) \\
+(\text { iv })+(v)\end{array}$ & 343.5 \\
\hline \multirow{5}{*}{ 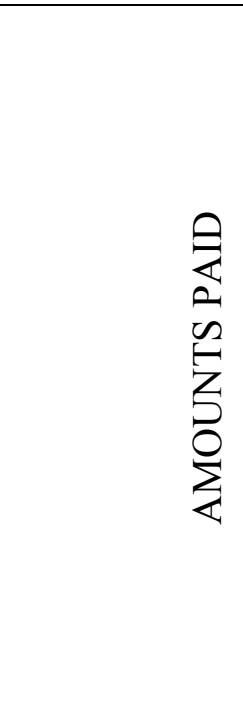 } & a) Repayment of IMF credits & 11.5 \\
\hline & $\begin{array}{l}\text { b) Capital contribution to } \\
\text { ESM }\end{array}$ & 2.3 \\
\hline & $\begin{array}{l}\text { c) Contribution to EFSM } \\
\text { loans for Ireland and Portugal }\end{array}$ & 0.7 \\
\hline & $\begin{array}{l}\text { d) Contribution of BoG to } \\
\text { SMP purchases of Irish, } \\
\text { Portuguese, Spanish and } \\
\text { Italian bonds }\end{array}$ & 3.6 \\
\hline & Total (a) + (b) + (c) + (d) & 18.1 \\
\hline \multicolumn{2}{|c|}{ NET AMOUNT RECEIVED } & 325.4 \\
\hline
\end{tabular}

Source: Sinn (2015: 7). 
Let us go item by item. The first loan agreement, announced in May 2010, consisted of bilateral loans from Eurozone countries plus loans from the IMF. Though the sum originally authorized was $€ 110$ billion (of which $€ 80$ billion would have been provided by Eurozone countries, and $€ 30$ billion by the IMF), only $€ 73.2$ were effectively disbursed, with $€ 52.9$ billion granted by Eurozone members and $€ 20.3$ billion by the IMF. The difference between the amount originally authorized and the sum effectively disbursed was later added to the second package, which was implemented in February 2012. Since the disbursement of credit was tied with the fulfilment of the reform measures included in the Memorandum of Understanding (MoU), and since the Troika judged that implementation of those measures was lacking, only $€ 142.6$ billion of the credit committed in the second package was actually transmitted to Athens, with $€ 130.9$ billion disbursed by the EFSF and $€ 11.7$ billion paid by the IMF. Sinn omits an extra $€ 10.9$ billion that were lent by the EFSF to the Hellenic Financial Stability Fund (HFSF), for which Greece had to pay the administrative costs and that was returned to the EFSF in February 2015. Including that amount in the sum, the total financing by the EFSF up to December 2014 reached $€ 141.8$ billion, bringing the combined assistance of the first and second packages to $€ 226.7$ billion, as reported by Mouzakis (2015).

Sinn includes other items in the public credit granted to Greece. Notably among them, one can find the TARGET2 liability position of the $\mathrm{BoG}$ with respect to the Eurosystem, which stood in March 2015 at $€ 96.4$ billion. ${ }^{5}$ He also lists the remaining Greek bonds in the hands of the ECB, acquired through the SMP programme established in 2010.These, according to Sinn, amounted to $€ 17.2$ billion by the end of March 2015.

The last item referred to in the amount of official credit received deserves examination, as it highlights (together with the TARGET2 liabilities sums) a main weakness of Sinn's analysis. The author calculates the maximum amount of banknotes the BoG should issue, as the "share of Greece in the paid-in capital of the Eurozone's central banks times the monetary base of the euro countries as a whole," valued at the end of June 2010 (Sinn, 2015: 4, fn. 7). The Greek share of the ECB's capital is determined by the mean value of Greece's share of the Eurozone's total population and GDP. According to

\footnotetext{
${ }^{5}$ TARGET2 liabilities of the BoG peaked in November 2011 at $€ 109.3$ billions. Since 2010 , their lowest level was in June 2014 at $€ 30.5$ billions. In Section IV we will discuss the concept and its interpretation in more detail.
} 
this rule, the BoG issued $€ 14$ billion in excess of its capital key in the ECB, which, Sinn contends, constitutes "an overdraft facility at the expense of other countries", since it allows Greeks to purchase goods, pay back debts and acquire assets.

Sinn discounts from the gross amount "received" by Greece, the sums it has already paid back to the IMF, which at the end of March 2015 totalled $€ 11.5$ billion. He also nets out the Greek contribution to the capital of the ESM ( $€ 2.3$ billion). The last two items represent "Greek shares," i.e., the share that Greece "contributed" to the EFSF and the outstanding share of government bonds from "periphery countries" (i.e. Ireland, Italy, Portugal and Spain) that the BoG bought under command of the ECB as part of the SMP programme, just as other National Central Banks (NCBs) bought Greek bonds.

The amount "paid" by Greece, then, totals $€ 18.1$ billion. Sinn counts the total financial assistance provided by official lenders, i.e. the Troika, to Greece, at $€ 325.4$ billion, up to March 2015. This amount is certainly higher than most accounts. Some estimates suggest that "aid" amounted to around €243 billions (Truth Committee, 2015: 22), but that includes money that was "pledged" but not effectively disbursed. Adjusting for this would leave official assistance at $€ 215.8$ billions, as noted in Table 1 . Other estimates fail to take into account amounts already repaid by Greece, such as some IMF loans. Some accounts include acquisitions of Greek government bonds through the SMP programme.

The main difference, however, arises because Sinn includes certain items that are ignored by others, notably the TARGET2 Greek liabilities and the "over-issuance" of banknotes by the BoG. This amounts to a difference of $€ 110.4$ billion by March 2015 . In the next section we will critically analyse these steps. First, however, we present Sinn's argument supporting the assertion that "[t]wo-thirds of the public credit was thus apparently used to finance capital flight and one-third to finance the current account deficit - ultimately the living standard that could not longer be financed with the income of the Greek citizenry" (p. 16).

\subsection{Where did that "aid" go?}

The relevant issue is not only how much money was lent to Greece, but also where it eventually went. Here, instead of actually going through an exposition of public reports and publicly available data specific to the issue, Sinn adopts a different approach. He 
conflates the public deficit with the current account deficit, and by making use of balance of payments aggregates he infers the destiny of the credit provided. He relies principally on two main statistics to draw his conclusions: the accumulated current account deficit since the start of the Greek crisis, and the "net foreign debt," i.e., the international investment position of Greece. In Sinn's paper, Figure 7 captures the movements of the different components of public credit granted to Greece (as detailed above) against the background of these two variables. We reproduce his figure, presenting it as Graph 1. For clarification, what Sinn calls "fiscal rescue credit" is the sum of the first and second rescue package, as they were disbursed.

Sinn sets 2008 as the beginning of the Greek crisis and the granting of public credit by the institutions of the Troika, since it is the year in which Greek liabilities in TARGET2 started to mount. Since a current account deficit implies net borrowing from the rest of the world, in Sinn's interpretation the credit covering the current account balance benefited the Greek population by helping sustain its standard of living without all the adjustment required. It is remarkable that TARGET2 liabilities rose almost one-to-one with the accumulation of current account deficits, something important to keep in mind when analysing Sinn's argument.

If the net investment position or net foreign debt is lower than the total rescue credit, this implies that there has been an increase in some external asset over the same time period as the borrowing. The graph shows that in fact the rescue as calculated by Sinn was $€ 104$ billion higher than net foreign debt in March 2015. This leads him to assert that almost a third of the Troika's "rescue credit" has been devoted to the acquisition of external assets by Greek nationals, while a third was financing the current account deficit, i.e., higher standards of living than what Greek production could afford. 


\section{Graph 1}

Public credit, cumulative current account deficits, and foreign debt

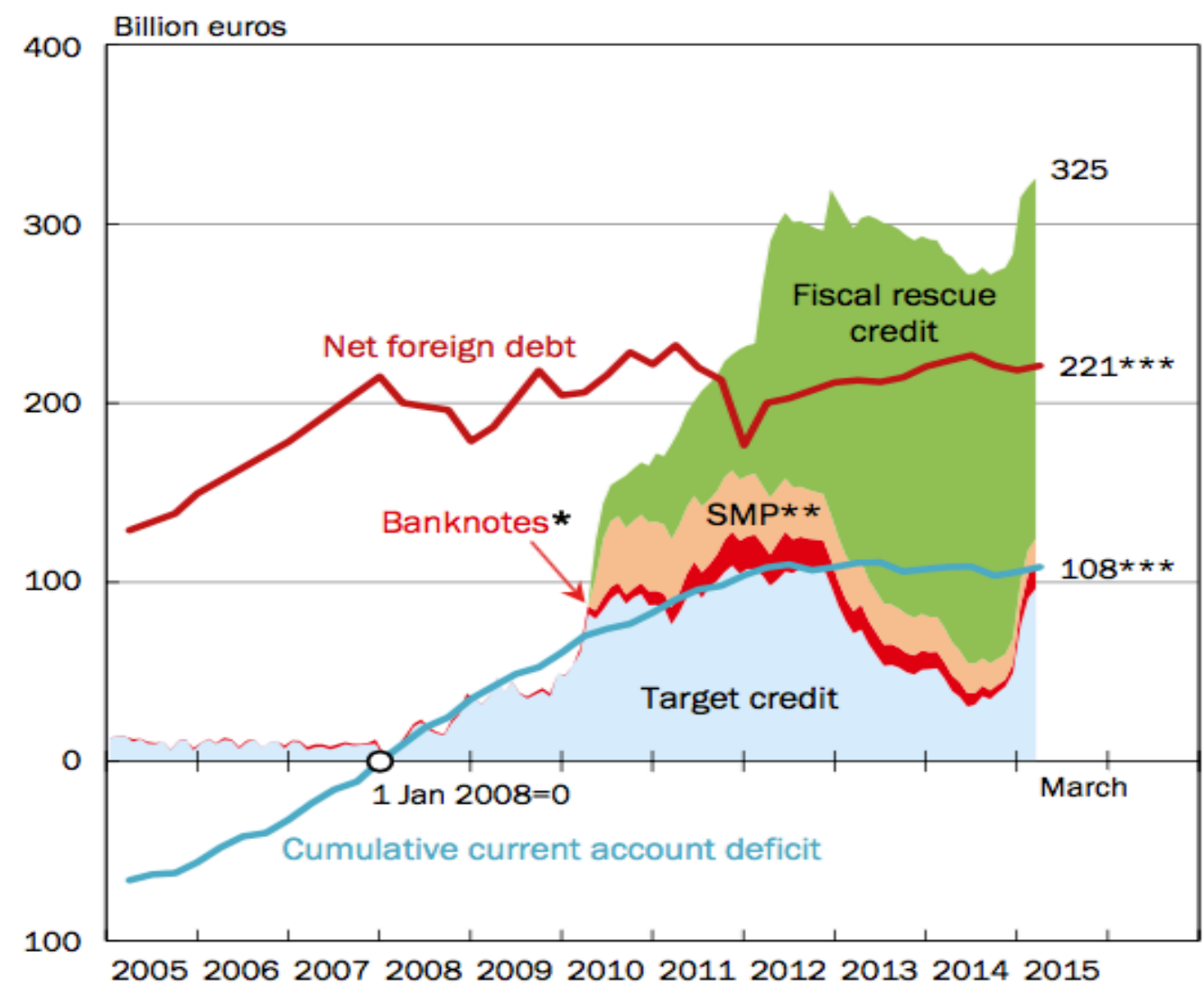

- Liabilities of the Greek central bank to the Eurosystem due to over-proportionate banknote issuance.

- Greek government bonds bought by other Eurosystem NCBs within the framework of the Securities Markets Programme (SMP) minus the government bonds of other countries bought by the Greek central bank under the SMP.

Estimate: January to March 2015.

Source: $\operatorname{Sinn}(2015: 15)$

\section{SINCE WHEN WAS GREECE “ASSISTED”?}

Critical to Sinn's calculations is the choice of 2008 as the point at which public assistance began. This choice is based on the assertion that the financing of the current account deficit from that date qualifies as assistance. Is this dating justified? We would claim not.

The 2008 crisis, and particularly the Lehman bankruptcy in mid-September 2008, fostered a financial panic and a retrenchment of (cross-border) bank lending, with banks in the United States, United Kingdom and major European countries moving capital out of their branches and subsidiaries towards their home countries in a typical "sudden 
stop" fashion. Countries like Ireland that had a housing bubble fuelled with foreign credit were left heavily damaged, even though their bubble burst a year before. Spain also had similar characteristics such as a real estate bubble and a large current account deficit, the inverse of a massive capital account surplus, and private financial flows that suddenly reversed course.

Governments all over the world had to provide substantial assistance to their banks, with Germany approving a $€ 480$ billion rescue to its banks (Der Spiegel, 2008a, 2008b). In the case of Greece, the then government of Karamanlis provided an aid package to Greek banks amounting to $€ 28$ billion, though only $€ 5$ billion were provided as recapitalization funds, while the rest represented public guarantees (Truth Committee, 2015: 17).

\section{Graph 2}

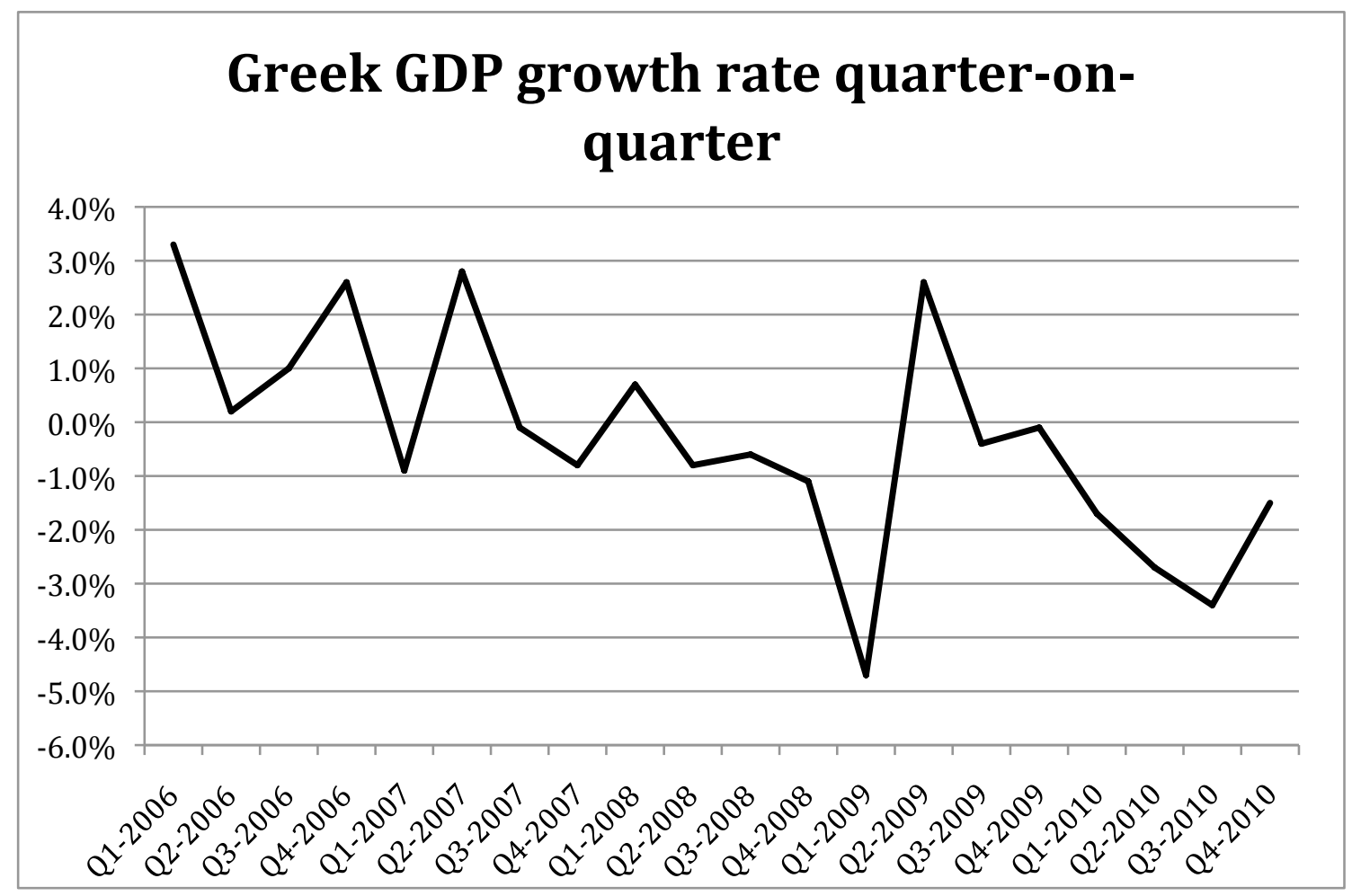

Source: OECD database.

But was this the beginning of the Greek crisis? In our view, two key indicators clearly suggest otherwise. The first indicator is the quarter-on-quarter rate of change of Greek 
GDP. Graph 2 shows this. One can observe that by the second quarter of 2009, the Greek economy was recovering. This was most likely as a result of the same measures that Sinn criticizes, i.e. a strong fiscal stimulus programme, combined with income policies, which in essence did not differ much from other stimulus packages elsewhere in Europe. ${ }^{6}$

From a more financial point of view, one can also look at its bond yields (our second indicator), which tell a story different to the one told by Sinn. Graph 3 shows the yields on the 10-year German and Greek government bonds from 2005 to May 2010, right after Greece declared the loss of access to financial markets.

\section{Graph 3}

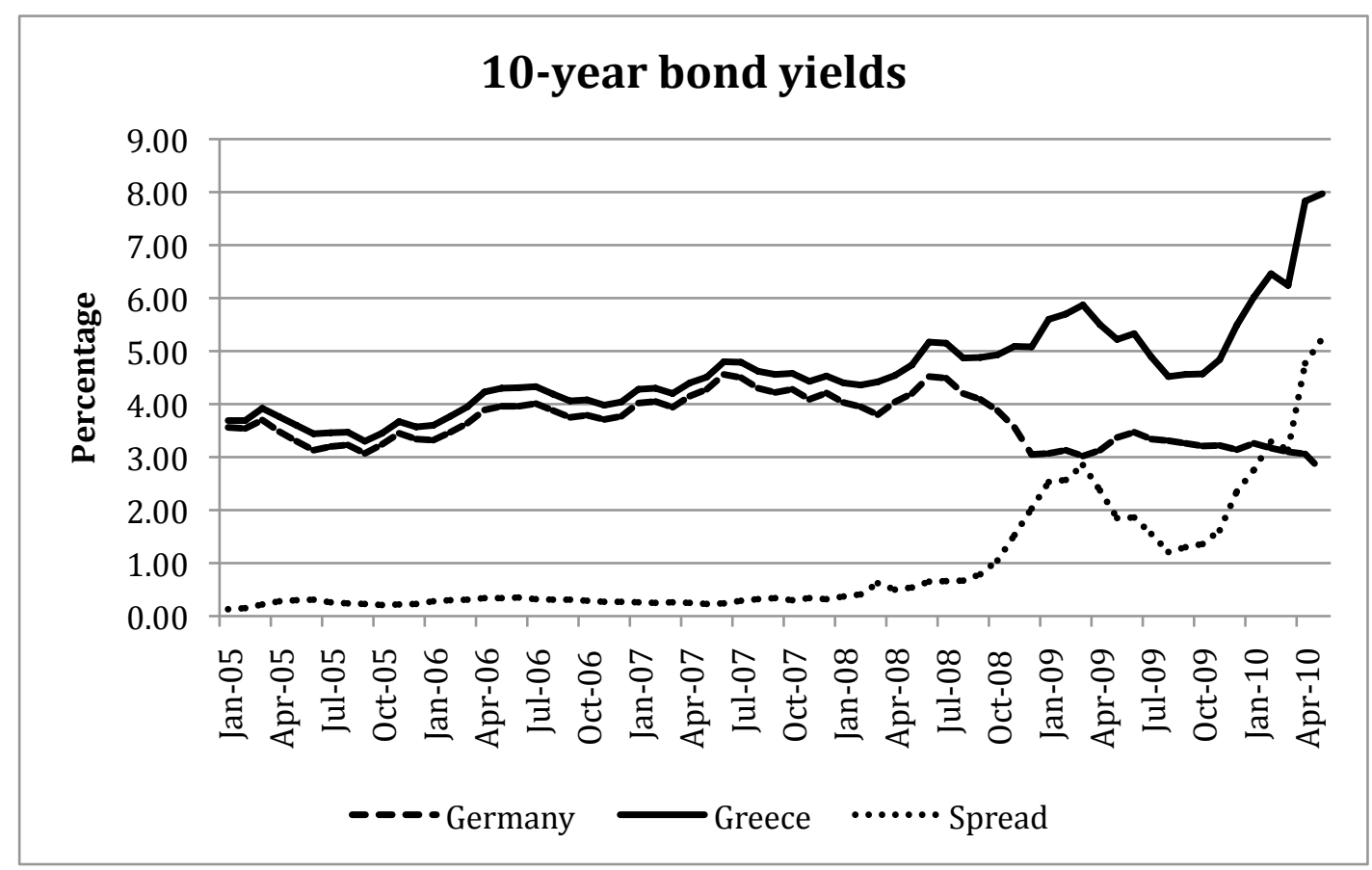

Source: Federal Reserve Bank of St. Louis.

The spike in credit spreads between Greek and German bonds started in September 2008, jumping from $0.79 \%$ to $1.05 \%$ in October, and from then on rising by half of a per cent each month until February 2009. The peak came in March 2009, with a spread

\footnotetext{
${ }^{6}$ If anything, the stimulus package implemented in Germany as a response to the global financial crisis was larger than most of the rescue packages implemented in other Eurozone and advanced countries (Vail, 2008).
} 
of $2.85 \%$. Notice that the rise in spreads reflected not only an increase in Greek bond yields, which rose from $4.87 \%$ in August 2008 to 5.87\% in March 2009, but also a reduction in German yields, which fell from $4.20 \%$ to $3.02 \%$ in that same period. That shows a retrenchment of banks from Greece and other periphery European countries to Germany (and France), considered to be the main safe haven in the Eurozone.

Crucially, however, the spread then fell by more than half from March to August 2009, reaching as low as $1.21 \%$. Greek government yields were $4.52 \%$ in that year, similar to 2003-2007 levels. The Greek government had a series of bond issuances, in March, April, May and June 2009, though the lowest interest rate it was offered was $4.3 \%$ on a 3-year bond issued in May 2009 (Truth Committee, 2015: 19). Strangely, it did not issue any bond in the third quarter of 2009, which saw the lowest yield levels after the Lehman crisis.

This renewal of appetite for Greek bonds (with foreign claims of German banks vis-àvis Greece rising 5 billion dollars from the second to the third quarter of 2009) may have something to do with the implementation in June 2009 of the first round of "Longer-Term Refinancing Operations" by the ECB (Kaminska, 2015). By accepting government bonds as collateral for liquidity operations, the ECB fostered a new round of sovereign debt purchases, not only to Greece but also to other periphery Eurozone countries like Spain or Portugal. The ongoing current account deficit was being financed by inflows from foreign banks. It was only in December 2009 that the economic situation deteriorated irreversibly, with spreads spiking above $2 \%$ and a sudden stop in capital inflows. The economy had officially entered a recession, which would be aggravated by the austerity measures implemented by Papandreou as soon as he took over as Prime Minister. Blustein (2015: 3) says that "conversations" between Papandreou and the then Managing Director of the IMF, Dominique Strauss-Kahn, only started in late 2009, when Papandreou came to power. If there were no prior negotiations previous to that time, it makes little sense to state that the financial assistance started in 2008, least of all from January 2008, as Sinn does. 


\section{TARGET2 BALANCES, CURRENT ACCOUNT DEFICIT, AND CAPITAL FLIGHT}

\subsection{What are those TARGET2 balances after all?}

As we mentioned, Sinn dates 2008 as the beginning of public assistance to Greece, because he counts the financing of the current account deficit from that date as "help." This financing was registered as an increase in the TARGET2 liabilities of the BoG.

Numerous papers have been written on this topic, including the works of Bindseil and König (2011), De Grauwe and Ji (2012), ECB (2013) and Whelan (2014) among others. There are those that consider TARGET2 credit and liabilities as being harmless, those that consider them to be symptoms rather than causes of problems, and those that attach great dangers to the mounting credit and liabilities that National Central Banks (NCBs) hold against each other. Sinn $(2014,2015)$ can be counted among the latter.

Sinn's interpretation is that TARGET2 claims result from one NCB financing other NCBs. His argument, repeated in Sinn (2014), is that Target balances are "indeed overdraft credit between the NCBs" (p. 5). Take the example of the Emergency Lending Assistance (ELA) credit granted by the BoG to Greek banks, which then make transfers to bank accounts outside Greece but still within the Eurozone. Sinn says that "the Greek central bank forces the other Eurosystem NCBs to grant it Target overdraft credit, since these NCBs must honour the payment orders to the benefit of Greek citizens; in other words, they must create money without getting a claim on the commercial banks in their jurisdiction, as is normally the case" (Sinn, 2015: 17). In that sense, "each euro in additional ELA credit that the Greek NCB creates today and lends through the banks to someone intent on capital flight, who then cables the money to another euro country, is a credit given by the respective foreign NCB to the Greek one, since the former has to issue central bank money to honour the payment order to a bank in its jurisdiction on behalf of the Greek central bank" (Ibidem).

But how accurate is Sinn's interpretation? What are those liabilities after all? Let us consider first the explanation of TARGET2 set forth by Frances Coppola (2015). 
The ECB has a clear definition of TARGET2. Quoting in full from its website ${ }^{7}$ : "TARGET2 is the real-time gross settlement (RTGS) system owned and operated by the Eurosystem. TARGET stands for Trans-European Automated Real-time Gross settlement Express Transfer system. TARGET2 is the second generation of TARGET. Payment transactions in TARGET2 are settled one by one on a continuous basis, in central bank money with immediate finality. There is no upper or lower limit on the value of payments. TARGET2 settles payments related to monetary policy operations, interbank and customer payments, and payments relating to the operations of all largevalue net settlement systems and other financial market infrastructures handling the euro (such as securities settlement systems or central counterparties)."

The key phrase, in our opinion, is that TARGET2 is a "real-time gross settlement (RTGS) system," that is, a payment system. In other parts of its website, ${ }^{8}$ the ECB explains that "as the operator of a payment system, a central bank offers settlement in central bank money. The central bank allows financial institutions to transfer funds that are held in accounts with that central bank among themselves. Central banks' payment systems are typically used for the final settlement of claims originating from interbank operations and so-called ancillary systems."

An RTGS system settles payments between individuals (or firms, or banks) within its area. They are usually under the property and control of central banks, since one of their duties is to guarantee the stability of the payment system (ECB, 2000). ${ }^{9}$ Table 2 shows bookkeeping entries for the case of exports from Germany to Greece, which are not financed by a German bank (i.e., a current account deficit not financed by a capital account inflow). This is a first step in explaining the dynamics of the financing of a current account deficit by a country whose banks issue an internationally accepted means of payment.

Suppose a Greek importer asks a Greek bank to lend him some money to buy a German good, be it a capital or durable consumption good. The bank grants that credit, and creates a bank deposit with that amount. The balance sheets of the importer and the Greek bank are as follow:

\footnotetext{
${ }^{7} \mathrm{http}: / /$ www.ecb.europa.eu/paym/t2/html/index.en.html ${ }^{8} \mathrm{http}: / / \mathrm{www}$. ecb.europa.eu/paym/t2/about/vision/html/index.en.html ${ }^{9}$ For a review of risks inherent to payment systems, and a description of RTGS system in the Euro area, see Kokkola (2010).
} 
Table 2a

\begin{tabular}{|c|c|c|c|}
\hline \multicolumn{2}{|c|}{ Greek importer } & \multicolumn{2}{c|}{ Greek bank } \\
\hline Assets & Liabilities & Assets & Liabilities \\
\hline+ Deposits & +Loans & +Loans & +Deposits \\
\hline
\end{tabular}

Now the Greek importer buys the good from the German exporter, transferring to him an amount equivalent to the value of the good. The German exporter then puts the money in his own bank account at a German bank. But in order to settle that transfer, the Greek bank must have an equal amount in its own account at the central bank (in this case, the BoG), which constitute its reserves. That account diminishes when the payment is made, while on the other side, the reserve account of the German bank at its own central bank (in this case, the Bundesbank) increases by the amount of the deposit received.

Table 2b

\begin{tabular}{|c|c|c|c|c|c|c|c|}
\hline \multicolumn{2}{|c|}{ Greek importer } & \multicolumn{2}{c|}{ Greek bank } & \multicolumn{2}{c|}{ German exporter } & \multicolumn{2}{c|}{ German bank } \\
\hline +Good & +Loans & +Loan & -Deposit & -Inventory & & +Reserves & +Deposits \\
\hline -Deposit & & -Reserves & & +Deposit & & & \\
\hline
\end{tabular}

The settlement system registers a decrease in deposits at the Greek bank, and an increase in deposits at the German bank, meaning that the payment, i.e. the transfer from the Greek importer to the German exporter, has actually been made. The transaction was settled through the transfer of deposits, which involved a reduction in the reserves of the Greek bank, and caused an increase in the reserves of the German bank. The same register happens when we analyse a capital flight by a Greek investor (or somebody with deposits at Greek banks) to a "safe haven" such as, say, Germany.

Table 2c

\begin{tabular}{|l|c|}
\hline \multicolumn{2}{|c|}{ Settlement System } \\
\hline & + Deposit at German bank \\
\hline & - Deposit at Greek Bank \\
\hline
\end{tabular}


The ECB has a somewhat different description. We will quote extensively from this source, as it lends itself to different interpretations. Its description is as follow: "When a bank makes a payment to another bank through TARGET, the current account of the payer at its NCB is debited and the current account of the recipient bank at its NCB is credited. (...) If the transaction is cross-border (...) it affects the aggregate current accounts of banks at the NCBs. The NCB of the payee sees a reduction in its current account and the NCB of the recipient bank sees an increase in its current account. At the end of each day, the central banks' balance sheets are adjusted by assigning to the central bank with a reduction in their current accounts a corresponding liability in TARGET, and to those with an increase in their current accounts a corresponding claim in TARGET." (ECB, 2013: 105).

We condense in the next table the records from a capital flight, including the records in TARGET2, with the imputation of TARGET2 claims and liabilities mentioned in the previous paragraph.

Table 2d

\begin{tabular}{|l|l|l|l|l|l|l|l|}
\hline \multicolumn{2}{|c|}{ Greek investor } & \multicolumn{2}{c|}{ Greek bank } & \multicolumn{2}{c|}{ German bank } & \multicolumn{2}{c|}{ TARGET2 } \\
\hline $\begin{array}{l}\text { +Deposit at } \\
\text { German bank }\end{array}$ & -Reserves & -Deposit & +Reserves & +Deposits & $\begin{array}{l}\text { +Claim } \\
\text { on BoG }\end{array}$ & $\begin{array}{l}\text { +Liability } \\
\text { with } \\
\text { Bundesbank }\end{array}$ \\
\hline $\begin{array}{l}\text {-Deposit at } \\
\text { Greek bank }\end{array}$ & & & & & & & \\
\hline
\end{tabular}

It may seem from this description that there is actually a granting of credit to the deficit national central banks. However on the same page the automatic and recording nature of TARGET2 claims and liabilities is made more explicit: "a transfer of funds implies a reduction in the deposits on the current account of the paying commercial bank at its $\mathrm{NCB}$ (NCB A) and an increase in those on the current account of the recipient commercial bank at its NCB (NCB B). (...) At the end of the day, NCB A displays a negative TARGET balance and NCB B a positive balance, each vis-à-vis the ECB as the central counterparty" (ECB, 2013: 105-106). 
The decentralized manner in which the Eurosystem implements its monetary policy (ECB, 2013: 107) implies that discretion exists only in the relation between the NCB and the banks under its jurisdiction, by the acceptance of collateral. There is no discretionary decision on the assignment of claims and liabilities between the ECB and the NCBs, these records being subordinated to the approval of lending from the NCB to the banks. ${ }^{10}$ With that provision, the NCB credits the account of the bank in need. So how was the current account deficit financed? In the same way as the current account deficit of the United States or the United Kingdom has been financed: through the issuance of liabilities accepted by the exporters as final settlement of the transactions. Up until the end of June 2015, when capital controls were implemented, the Greek banks issued Euros, just like German banks. Intra-Eurozone transactions were settled in the same way as intra-national transactions: by moving bank reserves from one bank to the other. Bank reserves are central bank money, as mentioned in the quotation above. The central bank money of the BoG is exactly the same as the central bank money of the Bundesbank. In other terms: the BoG can issue "Deutsche Marks." That is the very essence of the euro and, in our interpretation, the very motive of its existence.

It is therefore a contradiction to say that the loans granted to Greece were used to "retroactively finance the current account deficit." The current account deficit was contemporaneously financed. If Greek banks' reserves fell, they had to be replenished, and the way to do so is through credit from the BoG. The surplus NCBs receive money created elsewhere, just like China receives dollars created in the US as payments for its exports, which it later uses to acquire US Treasury bills. In the Eurozone case, since surplus NCBs do not have that possibility, they receive a small interest on their "credits," holdings of liabilities created by deficit NCBs, in this case the BoG. That is the reason why TARGET2 liabilities are recorded as foreign debt of the BoG in the statistics of the IMF.

\footnotetext{
${ }^{10}$ Another discretionary factor, however, is set by the limits to ELA funding imposed by the ECB. The above description is valid for ELA assistance within the boundary set by the ECB. Once those limits are reached, commercial banks cannot replenish their reserves and the payment system is impaired, as events at the end of June and July 2015 have shown.
} 


\subsection{What are the risks?}

The ECB requires banks to "hold deposits on accounts with their national central bank." " However, banks usually economize on reserves they hold at their central bank. In the Eurozone case the proportions on which the reserve requirements are based are computed at past levels of deposits and money-market paper, usually from the past month. So, faced with a drain in deposits, Greek banks are forced to borrow from their central bank, through ELA. The BoG expands its balance sheet by crediting Euros at the reserve accounts of Greek banks. These Euros are worth exactly the same as Euros credited by the Bundesbank as long as there are no capital controls to movements within the Eurozone. That is, the BoG issues the same type of "liabilities" as any other national central bank in the Eurozone.

In fact, that money is a liability of the whole Eurozone, that is, it is a liability of the ECB. That is why the creditor NCB has a claim vis-à-vis the ECB, which in turn has a credit position vis-à-vis the originator of such claim, the BoG. Credit and debit positions are not held by each NCB against the other, but rather against the ECB. Where would the potential risk appear?

The potential risk would become real, material, risk only in the case of a Grexit. Because we cannot exclude this as a possibility, we have to look into what might or will happen in case Greece leaves (or is forced to leave) the Eurozone. Sinn seems to believe that, in the case of Grexit, Greek nationals would have a capital gain in Euro terms if they keep their banknotes in Euros and their deposits at foreign banks. For instance, he says that "if the euro banknotes were not exchanged into drachma, but remained in the hands of the Greek population, in effect representing a parallel currency, a loss would be sustained by the rest of the Eurosystem inasmuch as these banknotes would be crowded out within Greece by the new drachma banknotes and be used for purchases in the rest of the Eurozone. This would entail losses related to goods that in effect 'disappear' from the rest of the Eurozone or, equivalently, losses in terms of a reduction in the potential for money creation via refinancing credit to commercial banks in the remaining Eurozone and, with it, the corresponding interest income" (Sinn, 2015: 22).

\footnotetext{
${ }^{11}$ Data on the calculation of the minimum reserves requirements are found in: https://www.ecb.europa.eu/mopo/implement/mr/html/index.en.html
} 
Unfortunately, the argument is problematic. Aside from the fact that goods exchanged for Euros would not 'disappear' but rather 'be bought' (which, needless to say, would count as exports), if Greece "Drachmatized" its economy but Greeks keep their Euros, either at German banks or in their safety boxes, the Eurosystem would not face any loss of the sort Sinn fears. Greeks can already use these Euros to buy German or French goods now (ignoring for now the capital controls which were established right after Sinn published his paper). Greek nationals would not be richer in euro terms, however redundant this claim may seem to be. On the contrary, it is most likely that those Euros would be spent buying cheaper Greek assets (such as real estate). Investors from the Eurozone would find it easier to acquire Greek firms and land. It is far more reasonable to expect, as has actually transpired, private capital outflows before the abandonment of the euro, and capital inflows afterwards. There is no reason to expect, besides, any reduction in the "potential for money creation in the remaining Eurozone," except for countries that would be expected to have a fate similar to Greece. In those cases, however, it is likely that ELA would also increase just like it did in Greece.

However, other risks might certainly materialize, risks to the other National Central Banks and losses that they (and their respective governments) may have to absorb. German banks use the inflows they receive to pay back credit granted by the Bundesbank and to park there as well any excess deposit inflows, which constitute liabilities of the Bundesbank. Authors like Tober (2013) fear that in case of a Grexit, that liability would survive, but the Bundesbank's claims against the ECB might not, or that the NCB might have to absorb the potential loss weighing on the ECB due to the BoG defaulting on its liabilities, according to its capital quota in the ECB. The collateralization of ELA lending is irrelevant in this case, since the collateral would most likely be redenominated in drachmas and the BoG would not have the eurodenominated assets to "pay back" the ECB. ${ }^{12}$ In that sense, Sinn is clearly right - the TARGET2 liabilities represent a potential risk for the Bundesbank and all the others NCBs, which would have to absorb losses according to their capital share in the ECB.

\footnotetext{
${ }^{12}$ It is important to notice that in January 2015 claims on the Greek government held by Greek Banks (both loans and securities) represented only $9.6 \%$ of their domestic claims, as shown in the aggregate balance sheet of the Greek financial sector. Most of the collateral posted as a requirement to obtain ELA funding were claims on the private sector, particularly loans.
} 
That scenario is a possibility, but not the only one, and it is certainly not unavoidable, even in the context of a Grexit. As we said, TARGET2 liabilities were central-bank money that the BoG created and that went to other Eurozone countries. Euros have to fly back to Greece for those liabilities to fall. In a not implausible scenario, Greece could actually leave the Eurozone without cancelling those liabilities, enjoy a period of current account surplus and/or capital inflows as mentioned before, and reduce those liabilities without any loss to the Eurosystem at all. Indeed, the TARGET2 settlement system is not restricted to Eurozone member countries: other central banks from noneuro area EU countries also joined voluntarily. A Grexit does not necessarily involve the BoG leaving the TARGET2 settlement system.

For the loss to actually happen, the ECB would have to "call back" all the Euros created by the BoG, which would fail to redeem those liabilities since it does not have the Euros, unless it confiscates every single euro in possession of Greek residents, and then a loss would have to be recognized by the ECB. However, TARGET2 claims are not callable, and as we said, there are possible scenarios in which a Grexit makes even more likely the cancellation of those liabilities.

The same holds for "excessive banknote issuance": there is no rule limiting how much cash an NCB can issue; in fact, a reasonable interpretation would be to say that it has to issue as much as demanded (taking into account the solvency of banks, of course) since the ECB mandate, that NCBs are required to pursue, includes the stability of the payment system, of which banknote issuance is perhaps the most emblematic feature.

All those arguments emphasize the discretionary nature of the loss recognition at the root of the risk. For instance, take the case of possible losses to the ECB of Greek defaults on its securities holdings, the most obvious case of potential loss for the ECB and its NCBs. Sinn states that, just like profits made from these purchases and other ECB assets are distributed to national governments, so would eventual losses be, constituting either directly or indirectly a potential burden for Greece's creditors. However, the discretion involved in such decisions is apparent when we see what happened to the profits made by the ECB on its purchases of Greek bonds, which it agreed to pass on to the Greek government. The fact of the matter is that it did not transfer them in full, using them rather as a carrot, in addition to the countless sticks, in negotiations with successive Greek governments. The Greek story has shown that rules 
are made up as we go (for instance, regarding the quality of the collateral that banks can post to obtain funding at their NCBs). Further, Sinn's assertion that "no institution can be liable for more wealth than it actually possesses [and this] also applies to an NCB" (Sinn, 2015: 21) misses contemporaneous examples like the Chilean Central Bank and the Czech Central Bank, both of which have negative net wealth, and even that of the Slovak Central Bank, a current member of the ECB (Hampl, 2014).

Sinn counts $€ 87$ billion as the total German exposure to Greece, directly and indirectly (including the bilateral loans, EFSF guarantees, IMF capital share, and ECB capital key), of which $€ 29.1$ billion represent potential "TARGET2 liabilities and liabilities due to over-proportionate issuance of banknotes" (p. 22). Taking for granted Sinn's argument regarding TARGET2 liabilities and focusing our attention on them, if Greece defaulted on those liabilities (which in March 2015 stood at $€ 96.4$ billion), the loss to the Bundesbank would amount to $€ 24.7$ billion (since its share in the subscribed capital of the ECB stands at $25.6 \%$ as of January 2015). On top of that, the remaining Greek bonds held by the Bundesbank related to the SMP purchases stood at 3.9 billion at the end of 2014 (Bundesbank, 2014: 83). To put those numbers into context, by the end of 2014 the Bundesbank held assets worth $€ 770.8$ billion, and provisions for general risks for up to $€ 14.4$ billion. The total German potential loss represents $7.6 \%$ of its primary government expenditure in 2014 , or $2.9 \%$ of the German GDP.

Furthermore, the losses corresponding to the potential Greek default of its TARGET2 liabilities are not allocated to the NCBs. The ECB's own website states that "in the event of a loss incurred by the ECB, the shortfall may be offset against (a) the ECB's general risk provision and the general reserve fund; and (b) the monetary income for the relevant financial year, following a decision by the Governing Council. Finally, any remaining net loss may be recorded on the Balance Sheet as losses carried forward and be offset against any net income received in subsequent years." 13 If Greece defaulted on its TARGET2 liabilities, then, the Bundesbank would only observe (ceteris paribus) reduced future income.

For another, a more comprehensive view of the potential losses to the rest of the Eurozone needs to consider potential benefits arising out of the Greek crisis. After all, the increase in Greece's TARGET2 liabilities was the obverse of capital flight to "safe

13 https://www.ecb.europa.eu/press/pr/date/2015/html/pr150219_1.en.html 
havens" that sent the costs of borrowing in those countries plummet. Dany et. al., (2015) calculate that because of that fall, the German public sector saved more than $€ 100$ billion in interest expenditures in the period between 2010 and mid-2015, an amount that is remarkably comparable to Germany's maximum potential losses if Greece defaults on all of its obligations, as calculated by Sinn (p. 22). While one can debate the exact magnitude of such positive spill over effects (on the rest of the Eurozone) of the Greek crisis, the same holds for the exact risks and potential losses due to Grexit. They are all issues on which reasonable people can disagree.

It should also be pointed out that Greek banks indebtedness with the BoG fell from its heights in February 2012 (at $€ 158$ billion), right in the middle of the debt restructuring, to as low as $€ 42.6$ billion in September 2014, which represents a fall of $73 \%$. Besides their recapitalization with European funds and some other private capital injection (about which more will be said later), there was a sizable deleveraging, with the stock of loans to non-financial corporations falling $14.6 \%$ in the same period ( $€ 38.5$ billion), recording 4 years of uninterrupted drop in credit. The data simply do not support Sinn's assertion that Greeks were taking loans from their banks to channel capital away from their country.

Summing up, losses may arise due to mounting TARGET2 Greek liabilities, in the event Greece leaves the Eurozone, but would only materialize as a loss of future income. Furthermore, their occurrence depends on political decisions, meaning that they are of a discretionary nature, and are not unavoidable. Under several plausible scenarios those losses do not materialize. Even if they do, the actual gains that public creditors (mainly the German government) enjoyed due to the fall in borrowing costs might be quite comparable to the maximum potential losses they may have to face if Greece defaults.

\section{SMP AND BANK RECAPITALIZATION}

\subsection{SMP Programme}

Sinn includes the purchases of Greek government bonds by the ECB, through the SMP programme, as part of the financial assistance provided by the Troika to Greece. We reproduce in full Sinn's argument in support of this description: 
"These bond purchases amount to a granting of public credit to the Greek government, because they enabled it to issue bonds up to the amount of that credit without having to attract private investors (who would have likely demanded higher yields). The purchases presumably [italics added, PB] led to private capital flows to Greece because the commercial banks that sold the Greek government bonds to their respective NCBs ultimately had to acquire these bonds in the Greek market. These capital flows lowered Greece's Target liability one-to-one, since they gave rise to net payment orders to Greece. Although booked as private capital in the balance-of-payments statistics, this capital flow was in fact a publicly induced credit by the other countries that stand behind the ECB" (Sinn, 2015: 5).

This argument is, however, refuted by the available evidence. The Greek government did not benefit from these purchases since it did not issue debt during the duration of the programme. Even though yields of the bonds directly involved in the programme did fall because of the SMP, the Greek government did not benefit from them. There was no inflow of capital to Greece due to the SMP purchases. There is no evidence to support the argument that foreign private creditors bought these bonds "in the Greek market," however captious that phrase is. There were no discernible diminutions in the holdings of Greek debt by domestic creditors, and since there was no issuance of Greek government bonds stimulated by SMP purchases, there is no foundation to sustain the argument. Bonds acquired through SMP purchases were held to maturity and they were prevented from suffering haircuts in the bond restructuring of 2012, so no net financial relief was provided to Greece. One can only conclude that these bond purchases were a flight channel for foreign creditors, who were overwhelmingly the sellers of the bonds, to get rid of their holdings without suffering major losses.

The SMP was announced and initiated in May 2010. Trebesch and Zettelmeyer (2014) analyse in detail the bond composition of SMP purchases and their effects on bond yields. They emphasize the non-transparent way in which these bonds were bought: "there were no publicly announced auctions and no transaction details were made public. The only way market participants could learn what was being bought was to participate in an actual transaction (i.e. be chosen as a potential buyer by the ECB), or to hear from another dealer that participated." (Trebesch and Zettelmeyer, 2014: 5). The bulk of bond purchases occurred in the first eight weeks after the programme was announced, a period in which Greece was already out of the financial markets. The 
bonds that were bought had a discernible secondary market, the targeted bonds had a rather short maturity, and the expansionary monetary effects of these purchases were nil, because the ECB sterilized the expansion in monetary base due to the purchases. The fall in yields was not uniform, with targeted bonds yields falling substantially more than those that were not acquired even in such opaque operating fashion. As we have shown, no decrease in TARGET2 liabilities happened during the operation of the programme.

The final evidence to refute Sinn's argument appears in the database compiled by Arslanalp and Tsuda (2014). ${ }^{14}$ These data show that Greek sovereign debt in the possession of foreign official creditors rose between the first and the second quarter of 2010 from $€ 13.1$ billion to $€ 64.6$ billion, an increase of $€ 53.5$ billion. This increase is explained not only by the IMF and bilateral loans extended in May 2010, but also by securities purchases, as the holdings of Greek public securities by official creditors rose $€ 32$ billion in that same period, while non-bank foreign creditors reduced their exposure (securities and loans) by €38.3 billion.

The opaque, targeted nature of the SMP purchases, their differential impact on the yields of targeted and non-targeted bonds, the fact that ECB holdings of those bonds were held to maturity without suffering any haircut (as would have been the case, had they remained in private hands), and the fact that there was no inflow of capital to Greece when the programme was announced, all refute the counting of such purchases as "publicly induced credit". Rather they support the argument of those that list the program as another channel that prevented foreign private creditors from incurring greater losses.

\subsection{Bank recapitalization}

Discussions regarding the "generosity" of the rescue packages provided to Greece often focus on the treatment of "original creditors," generally referring to other European banks. However Greek banks also held substantial portions of government debt, and

\footnotetext{
${ }^{14} \mathrm{An}$ often quoted source for data on holdings of Greek government securities and those of other countries is Merler and Pisany-Ferry (2012), which is a regularly updated database. We do not make use of this data, however, because unlike the database of Arslanalp and Tsuda (2014) it is affected by price revaluations. The importance of this issue can be highlighted by noticing that in the first European Banks stress test conducted in July 2010, banks were allowed to count their holdings of sovereign securities at face value, and the effects of eventual haircuts were not included in that stress test.
} 
were heavily affected by the default, so much so that they needed to be recapitalized. With the Greek government lacking the funds to face such task, they were included in the rescue packages, so that bank losses became public debt.

Most discussions of this issue begin by surveying the foreign claims of the banks vis-àvis Greek debtors, be it the public sector, Greek banks or private non-financial sector. Graph 4 shows the foreign claims of the banks of selected countries vis à vis Greece. According to this figure, French banks had a huge exposure on Greece, with German banks also having substantial exposure. However, things in fact were a little bit more complicated.

\section{Graph 4}

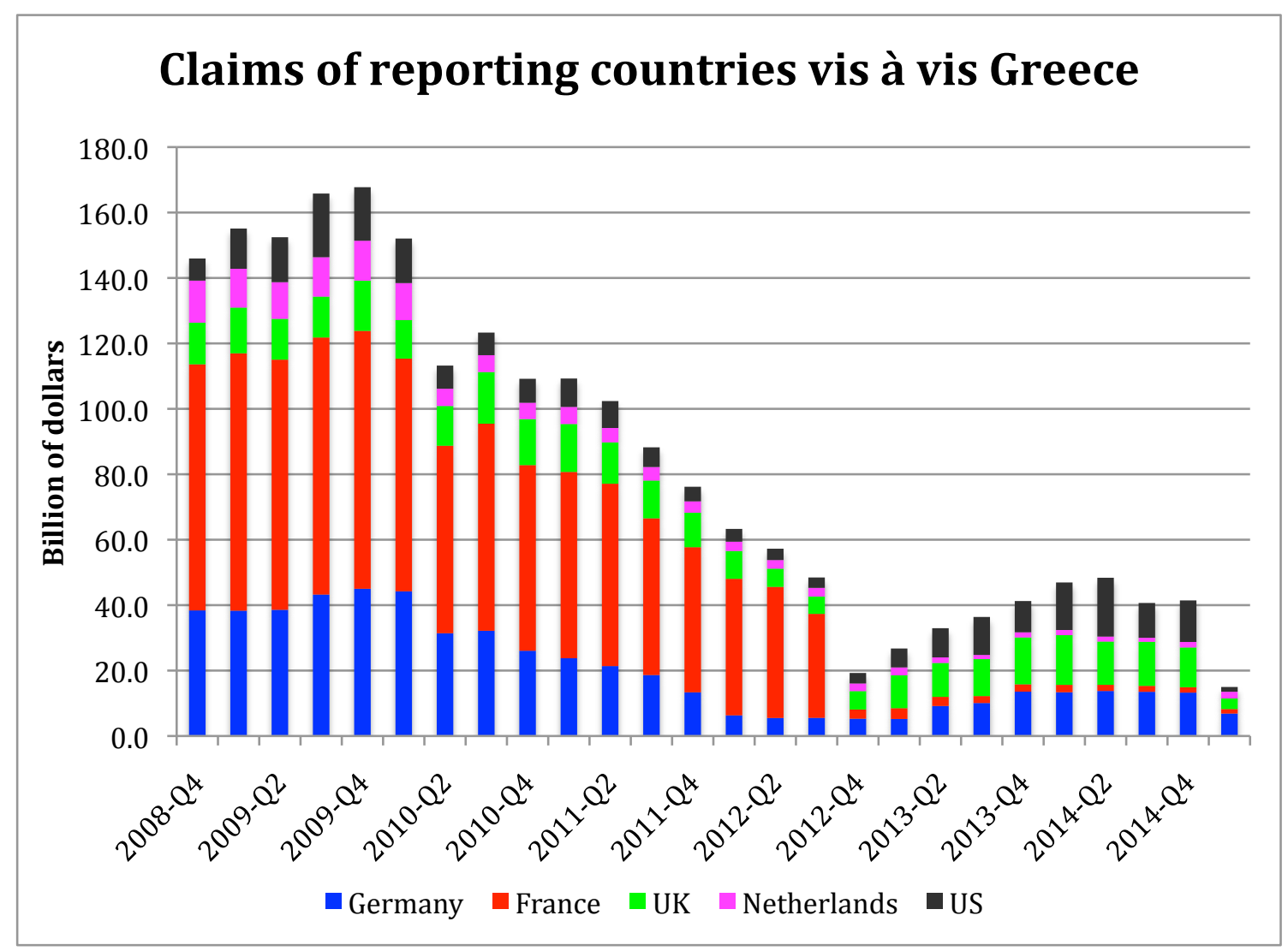

Source: BIS, consolidated banking statistics, ultimate risk basis.

Banks' exposure to Greece's sovereign debt could come in different flavours, but there are mainly three. Either they extend loans, buy Greek government bonds, or own Greek banks with their own high exposures. French banks had a large stake in two of the four 
major Greek banks. The data of the first stress test carried out in July 2010 by the European Banking Authority, as presented by Blundell-Wignall and Slovik (2010) shows that Greek sovereign debt on the books of French banks amounted to $€ 11.6$ billion, while the exposure of Greek banks amounted to $€ 56.1$ billion, though the aggregate balance sheet of the Greek financial sector raises that exposure (through loans and securities) to $€ 60.5$ billion as of July $2010 .{ }^{15}$ German banks, however, held $€ 18.7$ billion in their own books, as of July 2010, which represented around $12 \%$ of their Tier 1 capital (Blundell-Wignall and Slovik, 2010: 7-8). According to the BIS, in the first quarter of 2012, right before the debt restructuring, 78\% of French banks' claims were held by their Greek subsidiaries. Admittedly, by this time the home offices of these banks had divested a good share of their Greek government bonds, as the data by Arslanalp and Tsuda (2014) show. For instance, between the first and the second quarter of 2010, Greek sovereign debt in the possession of foreign banks fell from $€ 72$ billion to $€ 57.5$ billion, without taking into account price revaluations. The acute fall in exposure to Greek debt in 2010-2011, particularly in the case of German banks, is a powerful indicator of the destiny of official credit, either through rescue funds or the SMP. French banks also could transfer the exposure of the home company to their Greek subsidiaries. However, no explicit number for these can be given, as no data is available regarding who sold bonds to the ECB, who sold them to Greek banks or Greek pension funds, or who held the bonds to maturity and was caught in the debt restructuring.

Dan Davies (2015) makes the point ${ }^{16}$ that had Greece defaulted on its creditors in 2010 instead of March 2012, Greek banks would have gone into bankruptcy and depositors would have had much trouble getting their deposits back. In May 2010, Greek banks held $€ 54.4$ billion in loans and securities (bonds and Treasury bills) from their government, which represented $181 \%$ of their capital (net of provision for bad loans), as reported by the Bank of Greece. Since French banks could have responded to claims by Greek depositors only by losing their share of Greek banks' capital, Davies points out that "a write-off of all Greek government debt would have been a deep flesh wound for the German and French banks (around 6-7\% of total capital), but a complete wipe-out for the Greek banks (just under 100\% of capital and reserves).”

\footnotetext{
15http://www.bankofgreece.gr/Pages/en/Statistics/monetary/nxi.aspx

16https://medium.com/bull-market/2010-and-all-that-relitigating-the-greek-bailout-part-1a889d468e8ae
} 
The point is open to interpretation. There are two attenuating, if not counteracting, factors to Davies' argument, even if his main point is solid and well taken. When the time for a debt restructuring came, only a portion of the debt faced a haircut (official debt was not diminished) and the haircut did not amount to $100 \%$, the extreme scenario imagined by Davies. Even so, Greek banks did suffer substantially and had to be recapitalized, as we mentioned before. However it is not possible to specify the haircut that would have applied to them, in a much larger share of eligible debt (with the same haircut in absolute terms representing a much smaller percentage of total debt). So while Greek banks would certainly have needed some recapitalization it is impossible to predict the magnitude of the required assistance.

Which brings us to the second factor: who would have been (legally) obliged to provide the assistance? Davies assumes that French banks would only be liable for the share of capital proportional to their share of ownership of Greek banks. While that is clearly a possibility it is not the only one, though one can only speculate about it. It would have been perfectly reasonable for French banks to contribute to the capitalization of their Greek subsidiaries, as some did afterwards (HFSF, 2015: 4-6).

Davies admits, however, that the stability of European banks was a major concern of authorities at the time, by which he means major "core European" banks. Referring again to the data of European banks' exposure, we see that their holdings of Greek debt and other periphery bonds were unevenly distributed. For instance, Hypo Real Estate (which had already been rescued once by the German government) had an exposure of $€ 7.9$ billion to Greece, and if these funds had been written down by $100 \%$, the Tier 1 capital of Hypo Real Estate would have been totally wiped out ((Blundell-Wignall and Slovik, 2010: 9). It would have been serious enough to motivate further rescue operations by the German government. This supports the argument made by Thompson (2015) that the political stance adopted by Germany between May 2010, at the time of the first rescue, and Fall 2011, when the decision to restructure Greek debt was taken, largely followed the interest of German banks, which were more vulnerable to peripheral debt than French banks. This was true despite their smaller exposure as a result of their poorer capital to asset ratios and greater short term funding dependence (Thompson, 2015: 6-7). To this one might add the "rescue fatigue" of the German population regarding German banks' fragilities. In effect, German banks managed to reduce their foreign claims vis à vis Greece by a whopping 57\% (in dollar terms), 
compared to less than $40 \%$ of French exposure, with the caveat made above, that most of these claims were held by Greek subsidiaries rather than the home company itself. By the first quarter of 2012, German exposure had fallen to just $\$ 6.3$ billion.

The conclusion has to be that both foreign creditors and Greek depositors were ultimately protected by the timing and the way in which the rescues were implemented. Greek depositors did not face any losses, but the Greek state was further burdened with debt in order to recapitalize Greek banks. Quantifying alternative scenarios in terms of debt, percentages in debt haircuts and eventual (foreign and Greek) banking capitalization needs is virtually impossible.

\section{NET INVESTMENT POSITION AND CAPITAL FLIGHT}

Along with his claim that a third of the public credit granted to Greece was used to support living of standards, Sinn claims that another third was used to fund capital flight by Greeks, since public credit exceeds Greece net foreign debt, the obverse of its net investment position (NIP) as computed by the IMF Balance-of-Payments Statistics, converted to euro terms (and not in dollars, as in the IMF statistics). Sinn ignores, however, the "quadruple entry bookkeeping principle" in his analysis, which was implicit in the TARGET2 description we made above. This section is devoted to explain the mentioned principle. As a first approximation, one can say that there are four records for each transaction.

We have seen that TARGET2 cannot be considered public credit provided by the Eurozone to Greece, and the same goes for "excessive banknote issuance." That takes out $€ 110.4$ billion of the total "assistance" provided to Greece, as calculated by Sinn. We have also shown that SMP purchases were not of any assistance at all, which means that another $€ 17.2$ billion (as of March 2015) should have been subtracted from Sinn's estimate of "credit granted to Greece", leaving actual net financing numbers at $€ 197.8$ billion.

Now that we have clarified the conceptual mistakes inherent in Sinn's analysis let us focus on gross assistance. To allow a scenario most favourable to Sinn's argument we will omit debt repayment to the IMF, the contribution of Greece to the EFSF, and the share of the BoG in the SMP programme. That is, we are left with the full amount of the 
first and second rescue packages, totalling $€ 215.8$ billion in disbursed financial assistance, without referring to the pledged sums, which were higher, as we noted before. Part of this assistance was used to recapitalize Greek banks, particularly after the debt restructuring in March 2012. ${ }^{17}$ Greek banks suffered a loss of $€ 18.8$ billion on their stock of Greek government bonds between February and March 2012, as reported in the aggregate balance sheet of the Greek banking sector, and were recapitalized with funds provided by the Eurozone, receiving €29.5 billion between April and December 2012, according to records. This would have increased the gross foreign debt of Greece. However debt recapitalization was accomplished by the transfer of EFSF securities, thereby increasing Greek foreign assets and having a neutral impact on the national foreign debt. Sinn argues that if fiscal rescue credit increases while net foreign debt remains unchanged, this has to imply a capital flight by Greek nationals. However, this is actually a consequence of the quadruple bookkeeping principle. A more detailed discussion shows this clearly.

Suppose, for example, that the entire bailout was paid in cash. Greece would have received Euros "printed in other Eurozone countries," therefore reducing its TARGET2 liabilities, or even achieving a positive TARGET2 balance. There is an increase in a Greek liability (debt to the Eurozone) and an increase in a Greek asset (EFSF securities), and the exactly opposite record for the Eurozone. That is what we mean by "quadruple bookkeeping entry principle." Tables $3 \mathrm{a}$ and $3 \mathrm{~b}$ show this in simple terms. The first line in table $3 \mathrm{~b}$ repeats Table $3 \mathrm{a}$.

Table 3a: Financial assistance to Greece

\begin{tabular}{|l|l|l|l|}
\hline \multicolumn{2}{|c|}{ EFSF } & \multicolumn{2}{c|}{ Greece } \\
\hline+ Loan & + EFSF securities & +EFSF securities & +Loan \\
\hline
\end{tabular}

\footnotetext{
${ }^{17} \mathrm{Keep}$ in mind that we are also omitting any reference to the $€ 10.9$ billion that were returned to the Troika in February 2015, which was not used for the stated purpose of bank recapitalization.
} 
Table 3b: Repayment to private creditors

\begin{tabular}{|c|c|c|c|c|c|}
\hline \multicolumn{2}{|c|}{ EFSF } & \multicolumn{2}{c|}{ Greece } & \multicolumn{2}{c|}{ Private creditors } \\
\hline +Loan & + EFSF & +EFSF & +Loan & & \\
& Securities & securities & & & \\
\hline & & -EFSF & -Greek Gov. & +EFSF securities & \\
& & securities & Debt & -Greek Gov. Debt & \\
\hline
\end{tabular}

The neutral impact on the Net International Investment Position shows that one type of creditor was substituted by another, and that the positive impact on Greek indebtedness of the debt restructuring in March 2012 (with a decline of $€ 107$ billion in the face value of Greek debt, as calculated by Zettelmeyer et al (2013: 13)) was quickly erased by more official credit. A portion of that credit $(€ 29.7$ billion plus another $€ 4.9$ billion in accrued interests still owed from old bonds) was used as a "sweetener" to lure more creditors into the agreement, and a portion was dedicated to bank recapitalization ( $€$ 48.2). In the aggregate, capital flight happened by Greeks moving their deposits abroad, ${ }^{18}$ not by borrowing from domestic banks, since data shows that the stock of credit to the private sector fell uninterruptedly. This evidence does not support Sinn's argument that "out of public credit received during the crisis years, one-third was used to finance the current account deficit, one-third to repay Greek foreign debt, and onethird to bring Greek citizens' wealth abroad” (Sinn, 2015: p. 16). The next section looks more closely at actual data on the destiny of the rescue packages.

\section{SOME ACTUAL NUMBERS}

Mouzakis (2015) was the first to proffer detailed numbers in the discussion regarding the destiny of European financial assistance provided to Greece. The author lists amounts effectively disbursed, matching the numbers of Sinn (2015), before unused bank recapitalization funding of $€ 10.9$ billion was returned to the Troika in February 2015. The article looks at official documents and data to study the actual destination of

18 Domestic deposits (other tan the Government) at Greek Banks fell from $€ 242$ billion to $€$ 154 billion in June 2012, the lowest level up to the bank run that started in December 2014. 
bilateral and EFSF loans, and IMF lending. The graph that made such splash in public debate is reproduced here as Graph 5.

\section{Graph 5}

\section{Where did the money go?}

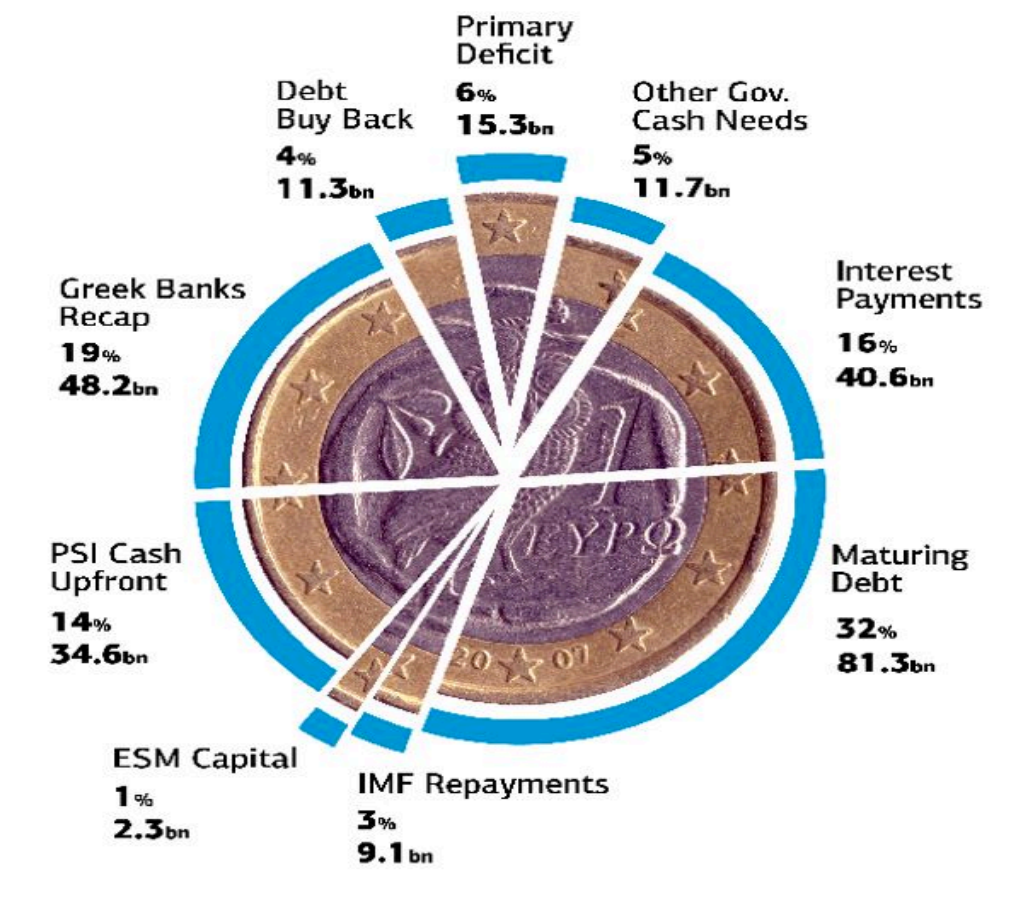

\section{MacroPolis}

Source: Mouzakis (2015)

Mouzakis' numbers, however, add up to $€ 254.4$ billion, almost $€ 28$ billion more than the amount effectively disbursed. By digging into official sources, specifically Programme reviews by the European Commission and data from the ECB Statistical Data Warehouse, we were able to reconstruct the time of the disbursements and the destiny of that assistance, as shown in Table 4. We only considered numbers for "debt maturing" running from May 2010 up to the third quarter of 2014, and "IMF repayment" sums running up to the third quarter of 2014, since the last disbursement to Greece was made in August 2014.

The numbers registered as payment of maturing debt are drawn from the European Commission reviews of the first and second Economic Adjustment Programme for 
Greece. In particular, data for 2010 and the first half of 2011 comes from the third review of the first programme (EC 2011a, p. 75), while for the second half, data was taken from the fourth review (EC 2011b, p. 45). For the period between 2012 and the third quarter of 2014, as well as the sums repaid to the IMF up until September 2014, data is taken from the fourth review of the second program (EC 2014, p. 71).

\section{Table 4}

\begin{tabular}{|c|c|c|c|c|c|c|c|}
\hline & Flows & 2010* & 2011 & 2012 & 2013 & 2014* & Total \\
\hline 0 & Disbursements & 31.5 & 41.5 & 109.9 & 31.9 & 11.9 & 226.7 \\
\hline 1 & Maturing debt & 10.5 & 28.3 & 12.9 & 11.1 & 17.8 & 80.6 \\
\hline 2 & PSI & & & 29.7 & & & 29.7 \\
\hline 3 & Debt buyback & & & 11.3 & & & 11.3 \\
\hline 4 & Bank capitalization & & & 41.0 & 7.2 & & 48.2 \\
\hline 5 & IMF repayment & & & & 1.7 & 5.1 & 6.8 \\
\hline 6 & ESM & & & 0.9 & 0.9 & 0.5 & 2.3 \\
\hline $7=1+2+3+4+5+6$ & Total flows & 10.5 & 28.3 & 95.8 & 20.9 & 23.4 & 178.9 \\
\hline $8=0-7$ & Difference & 21.0 & 13.2 & 14.1 & 11 & -11.5 & 47.8 \\
\hline
\end{tabular}

Sources: EC (2011a, 2011b, 2014); EC website about financial assistance to Greece, available at http://ec.europa.eu/economy_finance/assistance_eu_ms/greek_loan_facility/index_en.htm *Numbers for 2010 start from May (in the case of "Maturing debt); numbers for 2014 run up to the third quarter of the year.

What is recorded as "Difference" represents the amount left to cover the fiscal primary deficit and interest payments. The fact that in 2010 that number was very positive shows that the disbursement (bilateral loans and IMF funding, in the first programme) was very frontloaded. The excess of disbursements over debt-related issues (plus bank recapitalization) was sufficient to cover Greek primary deficit plus interest payments from 2010 to 2013. In 2014, as Mouzakis (2015) points out, the Greek government managed to cover many payments in without the assistance of official lenders. It issued 3 and 5-years bonds, and executed a series of repos that provided funds permitting it to cover debt repayments greater than its primary surplus.

The table shows that $74.9 \%$ of the financial assistance was used to repay debt, either due to maturing bonds and loans, through the PSI "sweetener" or through debt buyback, and to capitalize Greek banks. These factors sum to $€ 169.8$ billion. In February 2015, 
however, there was a reimbursement to the Troika of $€ 10.9$ billion which were disbursed for banking recapitalization purposes but left unused. The percentage of disbursement used to repay creditors rises to $77.9 \%$ if we include the repayment of IMF funds corresponding to the first package. ${ }^{19}$

Taking data from the ECB Statistical Data Warehouse, we can attempt to estimate the fiscal primary deficit and interest paid in these years. We chose to include the primary deficit incurred from the second quarter of 2010 to the third quarter of 2014, since the first disbursement of EU and IMF assistance were carried in May 2010 though I only count interest payments from the third quarter of that year. It is also worth noting that interest rate payments include a sum (€4.9 billion) that were recognized as accrued interests and included in the PSI "sweetener." From the third quarter of 2010 to the third quarter of 2014, interest payments totalled $€ 44$ billion. Finally, the total accumulated primary deficit from the second quarter of 2010 to the third quarter of 2014 sums to $€ 33$ billions. However, that number includes $€ 15.1$ billion used for the recapitalization of banks, registered as "capital injections recorded as capital transfers", according to ECB data, and split between 2011, 2013 and $2013 .^{20}$ If we do not exclude those $€ 15.1$ billion from the primary deficit, we would be double counting them. Graph 6 shows the sum of those items as compared to the disbursements per year represented by the dark blue line.

\footnotetext{
${ }^{19}$ If we include interest payments to these calculations, that percentage increases to $97.3 \%$. If we further add the repayment of IMF funds corresponding to the first package, we obtain $98.3 \%$. The amount might give the impression that there was barely any funding left for financing the primary deficit, but that is incorrect. As table 4 shows, the disbursements were frontloaded. During 2014, the Greek government covered many of its expenses (including debt repayment) with own funds, which compensate in a sense the financing of the primary deficit provided in the early years of the programme by the Troika.

${ }^{20}$ See "Capital injections recorded as capital transfers", https://sdw.ecb.europa.eu/browseSelection.do?DATASET $=0 \&$ REF AREA $=168 \&$ node $=968961$ $\underline{5}$. The sums discounted, because of that concept, from the primary deficit data amount to $€ 395$ million, $€ 265$ million and $€ 14,383$ million in 2011, 2012 and 2013, respectively.
} 
Graph 6

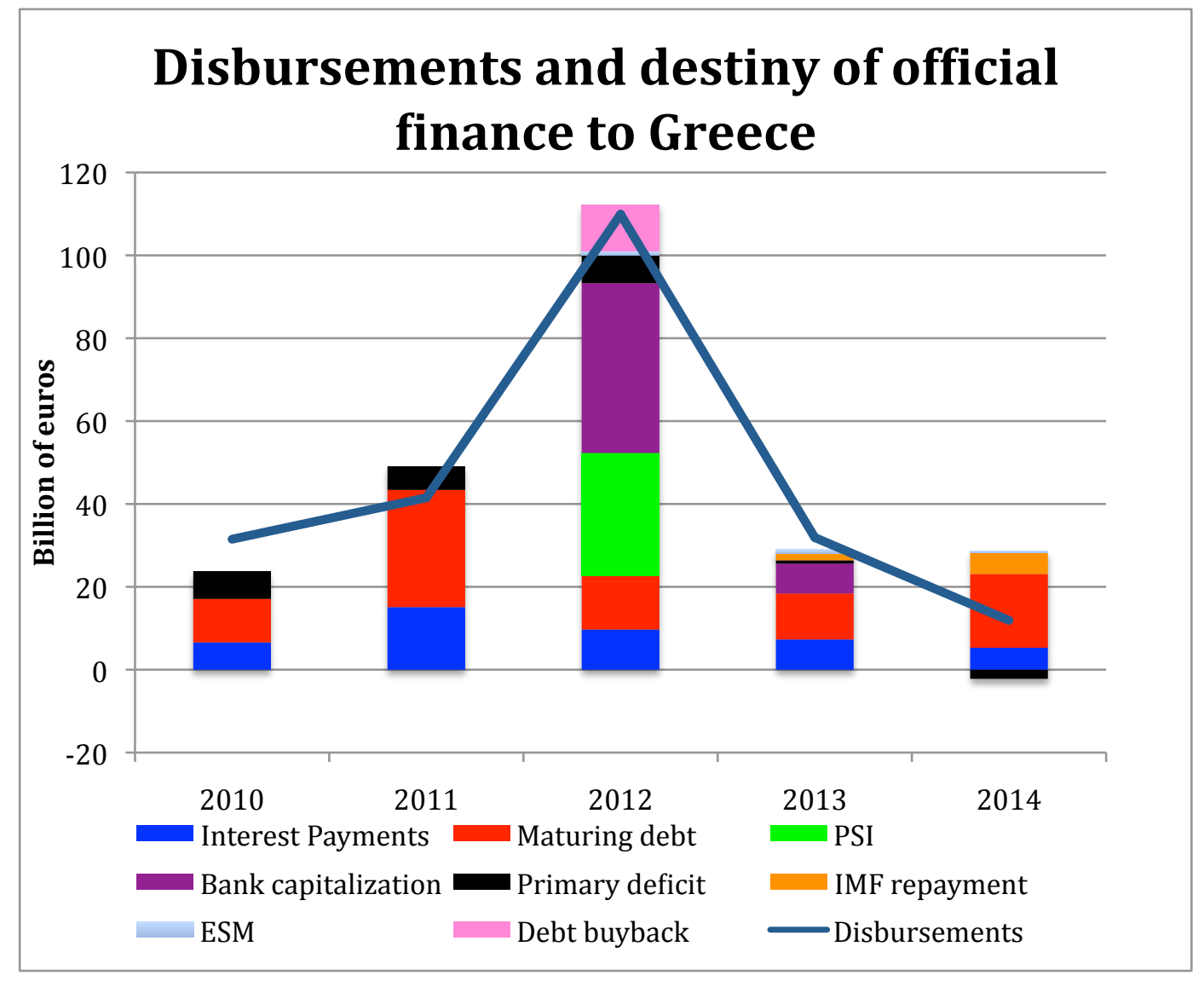

Sources: EC (2011a, 2011b, 2014); ECB Statistical Data Warehouse; EC website about financial assistance to Greece, available at http://ec.europa.eu/economy_finance/assistance_eu_ms/greek_loan_facility/index_en.htm *Numbers for 2010 start from May (in the case of "Maturing debt); numbers for 2014 run up to the third quarter of the year.

\section{CONCLUSION}

The discussion of a third bailout of Greece, and IMF insistence on the need for a restructuring of its public debt including haircuts on the claims of European official creditors have renewed debate about the benefits of the first two rescue package for Greece. The policy conditionalities included in the recent third bailout draw inspiration from those fostered in the previous ones.

The position expressed by Sinn (2015), which seems to enjoy popularity in German public opinion, is stark. Sinn states that a third of the public credit granted to Greece was used to finance the current account deficit, and therefore to maintain a living 
standard beyond Greece's means. Another third was used, according to his calculations, in financing a capital flight by Greek nationals, that is, their acquisition of foreign financial assets. Only the remaining part was used to pay Greece's creditors.

However, Sinn's analysis is based on misunderstanding of the money creation procedure in the Eurozone, and the implications of having an internationally accepted means of payments, that is, as a means to settle transactions. By issuing liabilities with such characteristics, within the monetary policy set by the ECB, the Bank of Greece can finance capital flights or current account deficits in the same fashion as the United States, the United Kingdom, or indeed any other Eurozone country that eventually faces similar difficulties. The effective financial "assistance" provided to Greece did not include the sums computed as TARGET2 liabilities. Sinn's criteria for counting "excessive banknote issuance" by the Bank of Greece lacks any legal foundation and exaggerates claims of potential risk to other Eurozone countries.

Further, Sinn's misunderstanding of the nature of the "quadruple entry bookkeeping principle" leads to misreading of the international investment position of Greece. The granting of a loan to Greece involves four records: an increase in an asset for the creditor (the loan), a liability for the debtor (the loan), and two accounts referring to the "material way" in which the loan was provided, either in cash or, as in Greece case, through securities issued by the European Financial Stability Fund, which are recorded as an asset in the International Investment Position statistics. Sinn fails to take these last two items into consideration, confusing securities granted to the Greek public sector with "acquisition of foreign assets" by Greek nationals.

Another article that paints the first two rescue packages to Greece in a favourable light is Bulow and Rogoff (2015). The calculations made by the authors include EU subsidies among the amounts disbursed, an unwarranted addition given the fact that these sums come from the EU general budget and are not provisioned in an extraordinary or special way to favour Greece. Without taking them into account, the total "net inflow" sum they come up with comes close to Mouzakis' numbers (roughly €25 billion) and somewhat above our own. To sustain their argument, Bulow and Rogoff point out that the "Greeks will benefit from having most of their debt transferred from private creditors to official creditors who are much less focused on repayment." But to sustain this rosy view, one would have to weigh this benefit against the costs of the 
conditionalities imposed by the official creditors when granting the lending, which is not obtainable from normal financial market data.

In their coincidence with Mouzakis' and our own account, however, Bulow and Rogoff reinforce the conclusion that the "rescue" programs by which successive rounds of loans were granted to Greece, with the already widely known conditions attached, were mostly a rescue of the original private creditors (including Greek banks) that had lent substantial amounts to Greece prior to its crisis and that were in great peril in the face of the crisis. Though definite numbers are difficult to determine due to data issues mentioned in Section V (particularly because it is not possible to know who sold their bonds holdings to the ECB, who sold them to other private investors such as Greek banks or pension funds, and who held them till maturity and/or was caught in the debt restructuring), one can certainly make educated guesses.

The purchases of Greek bonds conducted in 2010 by the ECB, as part of its SMP programme, are the clearest example of a rescue of foreign creditors by means of public officials, since it prevented original creditors (mainly foreign banks) from incurring losses in their holdings of Greek bonds without alleviating in the least the financial position of the Greek government. The fall in the exposure of German banks to Greece prior to the restructuring is the most telling evidence of such a rescue.

In the spirit of fairness it should be mentioned that depositors at Greek banks were spared losses resulting from the banks' bankruptcy and shutdown. Notwithstanding this, however, the assumptions involved in any counterfactual analysis only highlight the discretionary nature of the measures eventually adopted, as in any other politically motivated decision. One can confidently conclude, however, that the rescue packages do not tell a story of creditor generosity towards Greece. 


\section{REFERENCES}

Arslanalp, S. and Tsuda, T. (2014). Tracking global demand for advanced economy sovereign debt, IMF Economic Review, Vol. 62 (3): 430-464.

Bindseil, U. and König, P. (2011). The economics of TARGET2 balances, SFB 649 Discussion Paper 2011-035, Humboldt University, Berlin.

Blanchard, O. and Leigh, D. (2013). Growth forecast errors and fiscal multipliers, IMF Working Paper WP/13/1 International Monetary Fund, Washington, DC.

Blundell-Wignall, A. and Slovik, P. (2010). The EU stress test and sovereign debt exposures, OECD Working Papers on Finance, Insurance and Private Pensions, No. 4, OECD Financial Affairs Division, Paris.

Blustein, P. (2015). Laid low. The IMF, the euro zone and the first rescue of Greece, CIGI Papers No. 61, Centre for International Governance Innovation, Waterloo (Ontario).

Bulow, J. and Rogoff, K. (2015). The modern Greek tragedy, VoxEU.org, available at http://www.voxeu.org/article/modern-greek-tragedy

Bundesbank (2015): Annual Report 2014, Frankfurt am Main.

Coppola, F. (2015). Oh dear, Professor Sinn..., available at http://coppolacomment.blogspot.ch/2015/06/oh-dear-professor-sinn.html

Dany, G., Gropp, R., Littke, H. and Schweinitz, G. (2015). Germany's benefit from the Greek crisis, IWH Online 7/2015, Leibniz-InstitutfürWirtschaftsforschung Halle.

Davies, D. (2015). 2010 and all that - Relitigating the Greek bailout, available at https://medium.com/bull-market/2010-and-all-that-relitigating-the-greek-bailout-part-1a889d468e8ae

De Grauwe, P. and Ji, Y. (2012). What Germany should fear most is its own fear. An analysis of TARGET2 and current account imbalances, CEPS Working Document No. 368, Centre for European Policy Studies, Brussels. 
Der Spiegel (2008a). Germany responds to financial crisis: Parliament approves bank bailout package, 17 October 2008, available at http://www.spiegel.de/international/germany/germany-responds-to-finance-crisisparliament-approves-bank-bailout-package-a-584781.html

Der Spiegel (2008b). Germany's faltering bank bailout : The bottomless pit, 23 December 2008, available at http://www.spiegel.de/international/business/germany-sfaltering-bank-bailout--the-bottomless-pit-a-598207.html

ECB (2000). Role of the Eurosystem in the field of payment systems oversight, Policy Statement, European Central Bank, Frankfurt am Main.

ECB (2013). TARGET balances and monetary policy operations, ECB Monthly Bulletin May 2013: 103-114.

EC (2011a). The Economic Adjustment Programme for Greece. Third Review - Winter 2011, Occasional Papers No. 77, Directorate-General for Economic and Financial Affairs, European Commission, Brussels.

EC (2011b). The Economic Adjustment Programme for Greece. Fourth Review - Spring 2011, Occasional Papers No. 82, Directorate-General for Economic and Financial Affairs, European Commission, Brussels.

EC (2014). The Second Economic Adjustment Programme for Greece. Fourth ReviewApril 2014, Occasional Papers No. 192, Directorate-General for Economic and Financial Affairs, European Commission, Brussels.

Hampl, M. (2014). Old wine in new bottles. Why we need to take a sober look at central bank independence, available at http://omfif.cmail2.com/t/ViewEmail/j/BEBC40C98CD74605

HFSF (2015). Annual Financial Report for the year ended 31/12/2014, Hellenic Financial Stability Fund, Athens.

IMF (2013). Greece: ex post evaluation of exceptional access under the 2010 Stand-By Arrangement, IMF Country Report No. 13/156, International Monetary Fund, Washington, DC. 
Kaminska, I. (2015). A summary of the Greek crisis for the benefit of fintech people, FT Alphaville, available at http:/ftalphaville.ft.com/2015/07/06/2133636/a-summary-ofthe-greek-crisis-for-benefit-of-fintech-people/

Kokkola, T. ed (2013). The Payment System. Payments, Securities and Derivatives, and the role of the Eurosystem, European Central Bank, Frankfurt am Main.

Merler, S. and Pisani-Ferry, J. (2012). Who's afraid of sovereign bonds?, Bruegel Policy Contribution Issue 2012/02, Brussels.

Mouzakis, Y. (2015). Where did all the money go, Macropolis, available at http://www.macropolis.gr/?i=portal.en.the-agora.2080

Sinn, H-W. (2014). The Euro-Trap. On Bursting Bubbles, Budgets, and Beliefs, Oxford University Press, Oxford.

Sinn, H-W. (2015). The Greek tragedy, CESifo Forum June 2015, Special Issue.

Thompson, H.(2015). Germany and the euro-zone crisis: the European reformation of the German banking crisis and the future of the euro, New Political Economy, published online 13 May 2015, available at http://www.tandfonline.com/doi/abs/10.1080/13563467.2015.1041476?journalCode=cn pe20\#.VdoAg9Oqqko

Tober, S. (2013). Reluctant lone ranger: The ECB in the Euro Area crisis, in: H. StapfFiné (ed.): The Social Dimension of the Economic Crisis in Europe. Schibri-Verlag, Berlin.

Trebesch, C. and Zettelmeyer, J. (2014). ECB interventions in distressed sovereign debt markets: the case of Greek bonds, CESifo Working Paper No. 4731, Center for Economic Studies \&Ifo Institute, Munich.

Truth Committee on Public Debt (2015). Preliminary Report, Athens. Available at http://cadtm.org/Preliminary-Report-of-the-Truth

Vail, M. (2014). Varieties of liberalism: Keynesian responses to the great recession in France and Germany, Governance: An International Journal of Policy, Administration, and Institutions, Vol. 27 (1): 63-85. 
Whelan, K. (2014). TARGET2 and central bank balance sheets, Economic Policy, Vol. 29 (1): 79-137.

Zettelmeyer, J., Trebesch, C. and Gulati, M. (2013). The Greek debt restructuring: an autopsy, Working Paper No. 13-8, Peterson Institute for International Economics, Washington DC. 